\title{
THE ROLE OF A SCHOOL NURSE IN THE CARE OF A CHILD WITH DIABETES MELLITUS TYPE 1 - THE PERSPECTIVES OF PATIENTS AND THEIR PARENTS: LITERATURE REVIEW
}

\author{
VLOGA ŠOLSKE MEDICINSKE SESTRE PRI NEGI OTROKA S SLADKORNO \\ BOLEZNIJO TIPA 1 - VIDIKI BOLNIKOV IN NJIHOVIH STARŠEV: \\ PREGLED LITERATURE
}

\author{
Anna STEFANOWICZ ${ }^{1 *}$, Joanna STEFANOWICZ ${ }^{2}$ \\ ${ }^{1}$ Medical University of Gdansk, Faculty of Health Sciences with Subfaculty of Nursing and Institute of Maritime \\ and Tropical Medicine, Subfaculty of Nursing, Department of Nursing, Department of General Nursing, \\ Pediatric Nursing Workshop, Debinki 7, 80-211 Gdansk \\ ${ }^{2}$ Medical University of Gdansk, Faculty of Medicine, Department of Paediatrics, Haemathology \& Oncology, \\ Debinki 7, 80-211 Gdansk
}

\section{ABSTRACT \\ Keywords: diabetes mellitus type 1 , children, nurses, schools}

\section{IZVLEČEK}

Ključne besede: sladkorna bolezen tipa 1, otroci, medicinske sestre šole
Introduction: The aim of this literature review was to explore the views of parents and children with type 1 diabetes mellitus regarding having a school nurse.

Methods: Six databases were selected for the analysis. The research strategy was based on the PICO model. The research participants were children with type 1 diabetes mellitus and/or their parents.

Results: The present review of research papers includes 12 publications. The majority of works deal with the perspectives of children with type 1 diabetes and their parents on various aspects related to the role of a school nurse in the care of a child with type 1 diabetes:

- the presence of a school nurse;

- the role of a school nurse in the prevention and treatment of hypoglycaemia, in performing the measurements of blood glucose, and in insulin therapy;

- the role of a nurse in improving metabolic control of children with type 1 diabetes;

- a nurse as an educator for children with type 1 diabetes, classmates, teachers, teacher's assistants, principals, administrators, cafeteria workers, coaches, gym teachers, bus drivers, and school office staff;

- a nurse as an organiser of the care for children with type 1 diabetes.

Conclusions: According to parents and children with type 1 diabetes mellitus, various forms of school nurse support (i.e., checking blood glucose, giving insulin, giving glucagon, treating low and high blood glucose levels, carbohydrate counting) are consistently effective and should have an impact on the condition, improvement of metabolic control, school activity and safety at school.

Uvod: Namen tega sistematičnega pregleda literature je raziskati vlogo šolske medicinske sestre pri negi otrok s sladkorno boleznijo tipa 1 in pri podpori njihovih staršev.

Metode: Za analizo je bilo izbranih šest podatkovnih zbirk. Strategija raziskave je temeljila na modelu PICO. Zajeti so bili članki z opisi raziskav, v katerih so sodelovali otroci s sladkorno boleznijo tipa 1 in/ali njihovi starši.

Rezultati: Pregled literature vključuje 12 člankov. Večina se jih ukvarja s pogledom otrok s sladkorno boleznijo tipa 1 in njihovih staršev na vlogo šolske medicinske sestre pri negi otroka s sladkorno boleznijo tipa 1:

- prisotnost šolske medicinske sestre;

- vloga šolske medicinske sestre pri preprečevanju in oskrbi hipoglikemije, izvajanju merjenja glukoze $v$ krvi in inzulinski terapiji;

- vloga šolske medicinske sestre pri izboljšanju nadzora presnove otrok s sladkorno boleznijo tipa 1;

- šolska medicinska sestra kot vzgojitelj otrok s sladkorno boleznijo tipa 1, sošolcev, učiteljev, pomočnikov učiteljev, ravnateljev, administratorjev, zaposlenih $v$ kuhinji in jedilnici, trenerjev, učiteljev telovadbe, voznikov avtobusa in ostalega šolskega osebja;

- šolska medicinska sestra kot organizator nege otrok s sladkorno boleznijo tipa 1.

Zaključki: Po mnenju otrok s sladkorno boleznijo tipa 1 in njihovih staršev je podpora šolske medicinske sestre ( $t j$. preverjanje vrednosti glukoze $v$ krvi, dovajanje inzulina in glukagona, obravnava nizkih in visokih ravni glukoze, štetje ogljikovih hidratov) konsistentno učinkovita in vpliva na stanje, izboljšanje nadzora presnove, šolske dejavnosti in varnost otrok s sladkorno boleznijo tipa $1 \mathrm{v}$ šoli. 


\section{INTRODUCTION}

Type 1 diabetes mellitus (T1DM) is one of the most common chronic incurable diseases of the developmental age in Europe (1).

The treatment of T1DM includes insulin therapy with the insulin dose individually adjusted, self-monitoring, proper nutrition, physical activity and health education (2).

Children and adolescents with T1DM should attend public educational institutions $(3,4)$. Therefore, properly organised diabetes care for a child with T1DM at school or preschool is very important for the proper individual and social development of the child. A school nurse is one of the people who participates in the care of children with T1DM and improves the safety of children with T1DM in school (3-5).

School nurses should ensure a sense of psychological and physical safety, prepare other children to deal with a schoolmate with T1DM, instruct them how to help during the occurrence of hypoglycaemia or hyperglycaemia, help a child with T1DM to accept the disease, and provide them with support. The good co-operation between the child, parents and school nurse is a key part of successful treatment.

The aim of this literature review was to explore the views of parents and children with T1DM on having a school nurse.

\section{METHODS}

This literature review was conducted from January to May 2016. Six databases were selected for the analysis: Scopus, The Cochrane Database of Systematic Reviews, PubMed, Web of Science, Science Direct Journals (Elsevier) and the Main Library of the Medical University of Gdansk.

The following terms were set as advanced search criteria: diabetes mellitus, type 1 diabetes mellitus, children, school age, school nurses, school, school environment. The time frame inclusion criteria were years from 2001 to 2015 .

The research strategy was based on the PICO model ( $\mathrm{P}$ PATIENTS, I - an INTERVENTION, C - a COMPARISON, O - an OUTCOME), which allows the establishment of a precise clinical question (6).

In this work, the research question was as follows: What are the views of parents and children with T1DM on having a school nurse?
Thus, the following elements of the PICO process were determined as follows:

P - PATIENTS: school children with T1DM;

I - INTERVENTIONS: the presence of a nurse in the school;

C - COMPARISON: lack of nurses in the school;

0 - OUTCOME: the perceptions of children with T1DM and their parents.

The terms used for the search for selected literature were specified according to the MeSH dictionary (Medical Subject Headings) included in Table 1.

Table 1. Terms used to search the literature.

\begin{tabular}{|c|c|}
\hline $\begin{array}{l}\text { POPULATIONS/ } \\
\text { INTERVENTIONS } \\
{ }^{*} \text { MeSH term / }{ }^{* *} \text { free text }\end{array}$ & $\begin{array}{l}\text { OUTCOME } \\
{ }^{*} \text { MeSH term / ** free text }\end{array}$ \\
\hline $\begin{array}{l}\text { diabetes mellitus* } \\
\text { type } 1 \text { diabetes mellitus } \\
\text { children** } \\
\text { school age** } \\
\text { school nurses** } \\
\text { school** } \\
\text { school environment** }\end{array}$ & $\begin{array}{l}\text { perception* } \\
\text { perceptions of parents and } \\
\text { children }^{* *} \\
\text { having a school nurse }^{* *}\end{array}$ \\
\hline OR & OR \\
\hline
\end{tabular}

Operators AND and OR were used. The following criteria were applied to include particular works in the study: children, type 1 diabetes mellitus, parents, nurse, school nurse, school, perceptions, articles in English, and fulltext articles. The following criteria were excluded: type 2 diabetes mellitus, adults, animals, and articles in languages other than English. Works presented only in the form of abstracts were rejected.

Thirteen articles were rejected due to an inappropriate topic, character of the articles or poor quality (Table 2 ). 
Table 2. Assessment of undergraduate medical students in GP/FM: written exam.

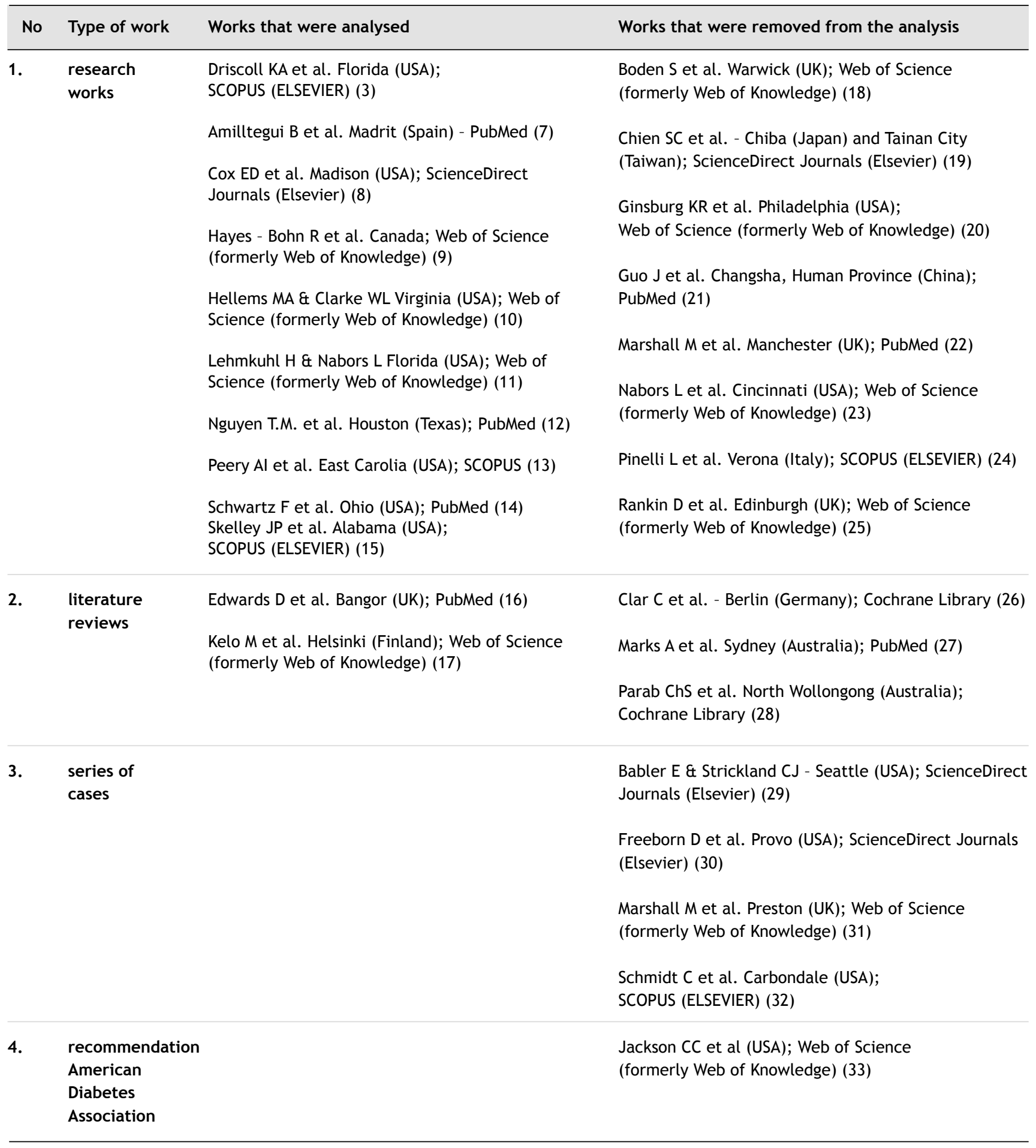


The final analysis included 10 research works and 2 literature reviews.

Three studies that were found in the collections of the Main Library of the Medical University of Gdańsk (2 BA and $1 \mathrm{MA}$ dissertations) were rejected. Those theses were not related to school nurses.

The PRISMA flow diagram illustrates the process of a systematic review (Figure 1) (34).

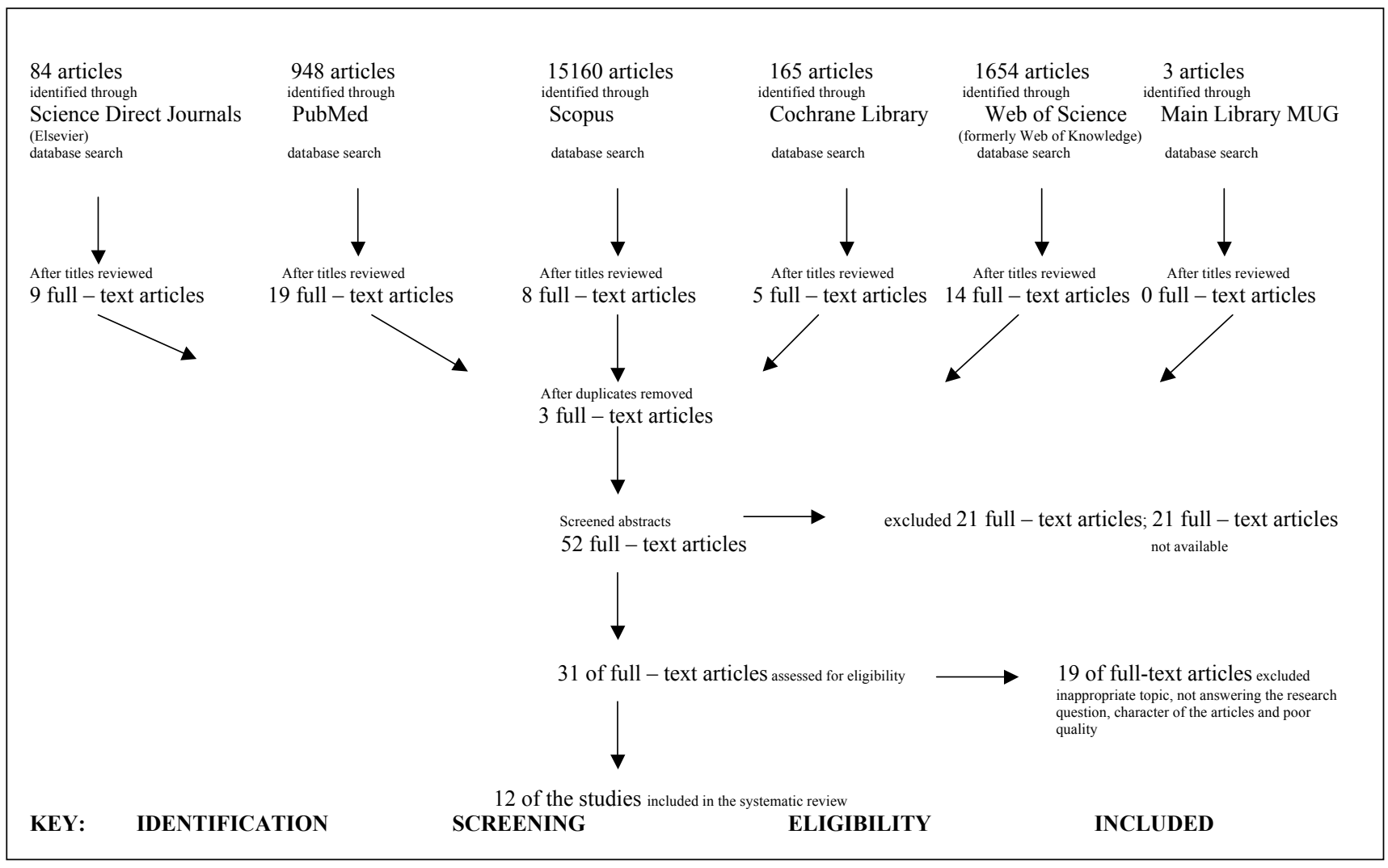

Figure 1. PRISMA Flow diagram (type 1 diabetes mellitus \& perception) (34). 


\section{RESULTS}

The presented review includes 12 publications. The majority of the studies deal with the perspectives of children with T1DM and their parents on various aspects related to the role of a school nurse in the care of a child with T1DM, including the following:

- the presence of a school nurse;

- the role of a school nurse in the prevention and treatment of hypoglycaemia, in performing measurements of blood glucose, and in insulin therapy;

- the role of a nurse in improving the metabolic control;

- a nurse as an educator for children with T1DM, classmates, teachers, teacher's assistants, principals, administrators, cafeteria workers, coaches, gym teachers, bus drivers, and school office staff;

- a nurse as an organiser of the care for children with T1DM.
The studies including the above-mentioned aspects are presented in Table 3. Table 3 also presents information about the evaluation of the work based on the principles of evidence-based medicine (35).

Table 3. The role of a school nurse in the care of a child with T1DM - the perspectives of parents and children.

\begin{tabular}{|c|c|c|c|}
\hline No & The perspectives & Works & Grade of Evidence (35) \\
\hline \multirow[t]{9}{*}{1.} & \multirow[t]{9}{*}{ the presence of a school nurse } & Amilltegui B et al. (7) & $2 b$ \\
\hline & & Cox ED et al. (8) & $2 b$ \\
\hline & & Edwards D et al. (16) & $3 a$ \\
\hline & & Hayes - Bohn R et al. (9) & $3 b$ \\
\hline & & Hellems M A. \& Clarke WL (10) & $3 b$ \\
\hline & & Kelo $M$ et al. (17) & $3 a$ \\
\hline & & Nguyen TM et al. (12) & $2 b$ \\
\hline & & Schwartz F et al. (14) & $3 a$ \\
\hline & & Skelley JP et al. (15) & $3 a$ \\
\hline \multirow[t]{4}{*}{2.} & \multirow{4}{*}{$\begin{array}{l}\text { the role of a school nurse in the prevention and } \\
\text { treatment of hypoglycaemia, in performing the } \\
\text { measurements of blood glucose, in insulin therapy }\end{array}$} & Driscoll K.A et al. (3) & $3 a$ \\
\hline & & Hayes - Bohn R et al. (9) & $3 b$ \\
\hline & & Hellems MA \& Clarke WL (10) & $3 b$ \\
\hline & & Lehmkuhl H \& Nabors L (11) & $3 b$ \\
\hline \multirow[t]{4}{*}{3.} & \multirow[t]{4}{*}{ the role of a nurse in improving metabolic control } & Driscoll KA et al. (3) & $3 a$ \\
\hline & & Edwards D et al. (16) & $3 a$ \\
\hline & & Lehmkuhl H \& Nabors L (11) & $3 b$ \\
\hline & & Nguyen TM et al. (12) & $2 b$ \\
\hline \multirow[t]{4}{*}{4.} & \multirow{4}{*}{$\begin{array}{l}\text { a nurse as an educator for children with T1DM, } \\
\text { classmates, teachers, teacher's assistants, } \\
\text { principals, administrators, cafeteria workers, } \\
\text { coaches, gym teachers, bus drivers, and school } \\
\text { office staff }\end{array}$} & Driscoll KA et al. (3) & $3 a$ \\
\hline & & Hayes - Bohn R et al. (9) & $3 b$ \\
\hline & & Lehmkuhl H \& Nabors L (11) & $3 b$ \\
\hline & & Peery Al et al. (13) & $3 b$ \\
\hline 5. & $\begin{array}{l}\text { a nurse as an organiser of the care for children } \\
\text { with T1DM }\end{array}$ & Peery Al et al. (13) & $3 b$ \\
\hline
\end{tabular}




\section{Level of Grade of Evidence (35):}

2b - Therapy / Prevention, Aetiology / Harm: Individual cohort study (including low quality RCT; e.g., $<80 \%$ followup)

- Prognosis: Retrospective cohort study or follow-up of untreated control patients in an RCT; Derivation of CDR" or validated on split-sample§§§ only

- Diagnosis: Exploratory** cohort study with good" " " reference standards; CDR" after derivation, or validated only on split-sample§§§ or databases

- Differential diagnosis / symptom prevalence study: Retrospective cohort study, or poor follow-up

- Economic and decision analyses: Analysis based on clinically sensible costs or alternatives; limited review(s) of the evidence, or single studies; and including multi-way sensitivity analyses

3a - Therapy / Prevention, Aetiology / Harm: SR (with homogeneity*) of case-control studies

- Prognosis

- Diagnosis: SR (with homogeneity*) of $3 \mathrm{~b}$ and better studies

- Differential diagnosis / symptom prevalence study: SR (with homogeneity*) of 3b and better studies

- Economic and decision analyses: SR (with homogeneity*) of $3 \mathrm{~b}$ and better studies

3b - Therapy / Prevention, Aetiology / Harm: Individual Case-Control Study

- Prognosis

- Diagnosis: Non-consecutive study; or without consistently applied reference standards

- Differential diagnosis / symptom prevalence study: Non-consecutive cohort study, or very limited population

- Economic and decision analyses: Analysis based on limited alternatives or costs, poor quality estimates of data, but including sensitivity analyses incorporating clinically sensible variations

The work of Amilltegui et al. is an observational survey study that aimed to identify the special needs of children with T1DM in the school setting from the parents' point of view and the difficulties associated with full integration experienced by their children, and to make an attempt to define interventions that can improve the situation of children requiring insulin therapy in the school setting. Among 320 schools participating in this study, 22\% employed a nurse. As a result of this study, 499 questionnaires were collected. As many as $70 \%$ of parents believe that a nurse trained to take care of children with T1DM should be in school (7).

Cox et al. developed and standardised the PRISM survey (Problem Recognition in Illness Self-Management) for children and young people, exploring the barriers in self- management experienced by children and young people with diabetes. This negative statement was an important finding: 'My child and I don't always trust the doctors and nurses.' 425 adolescents aged 13 years and older and parents of children aged 8 years and older participated in this study (8).

The work of Driscoll et al. evaluates parental perceptions of children's safety at school in the United States. Test results revealed that children in permissive states had significantly higher HbA1C $(\mathrm{N}=237$, mean $=8.8 \%+1.7 ; 73$ $\mathrm{mmol} / \mathrm{mol})$ than those in non-permissive states $(\mathrm{N}=198$, mean $=8.1 \%+1.2 ; 65 \mathrm{mmol} / \mathrm{mol} ; \mathrm{p}<0.0001)$. A focus on the education of the whole school team increases the safety of children with diabetes in school when a school nurse is absent. The school nurses and non-nurse clinic assistants were most commonly reported as specifically providing help with blood glucose monitoring and insulin administration (3).

Edwards et al. created a systematic review examining eleven interventions and barriers to achieving optimal self-control by children and young people aged 3-25 years with T1DM in educational settings. That review included studies of the 55 views of children and their parents regarding the skills of school nurses (16).

Hayes-Bohn et al. conducted a study to verify opinions, concerns and recommendations related to the care of children with diabetes at school. In this study, semistructured individual interviews were conducted, recorded, coded and qualitatively analysed. The study included 30 girls and their parents. The participants of the study recommend hiring full-time professional nurses (9).

Hellems and Clarke examined the safety of children with T1DM at school. The study involved 185 parents of children with T1DM attending 153 different schools in Virginia. Their survey study was conducted to determine whether the school staff helped students administer insulin and manage hypoglycaemia, and whether the care was performed in a safe manner. Among the parents, $69 \%$ claimed that full-time nurses were employed in schools, and $74 \%$ reported that their child with T1DM required assistance when administering insulin (10).

Kelo et al. created an overview of the findings including 22 works on self-care of school children with T1DM. In their conclusions, the authors emphasised that nurses must educate and assess a child's readiness to learn diabetes care (17).

Lehmkuhl and Nabors presented a pilot study evaluating children's perception of and satisfaction with the support from school nurses, teachers and classmates, and specifying the types of support expected by the children from each of these groups. The study examined 
31 boys and 27 girls between the ages of 8 and 14 years participating in a summer camp, and their parents. The study found that children were satisfied with the support they received at school but would also like to receive it during after-school activities. Children who reported more satisfaction with school care and had lower metabolic control achieved even lower glycated haemoglobin levels after 6 months of observation. Children who reported greater dissatisfaction with their diabetic status had higher glycated haemoglobin levels after 6 months of observation (11).

Nguyen et al. formulated a research hypothesis that the supervision and monitoring of children with T1DM performed by school nurses in the field of blood glucose level monitoring and insulin dosage significantly improves glycated haemoglobin levels. Thirty-six children with T1DM with glycated haemoglobin above $9 \%$ qualified for this study and were randomised into the intervention group and the control group. The intervention group underwent a threemonth intervention that involved teaching patients, their parents and school nurses the principles of insulin therapy and blood glucose measurements. Their average glycated haemoglobin value decreased by $1.6 \%$, indicating that this intervention improved metabolic control (12).

The work of Peery et al. describes how parents and teachers of 69 children out of a total of 86 perceive nursing interventions concerning the self-management of type 1 diabetes. Parents claimed that their children follow the rules of self-management better when the nurse is present in the school, conducts diabetes education, supervises and takes care of children. Based on the findings of this study, school nurses should be responsible for organising the care of children with T1DM at school, and conduct diabetes education and counselling for children, their parents and teachers (13).

Schwartz et al. conducted a survey involving 130 schoolaged patients with T1DM, their parents and school staff. Among the respondents, $76 \%$ claimed that the school nurse should be available at all times. The authors of this study claim that the number of nurses in schools is insufficient (14).

The aim of the study by Skelley et al. was to evaluate parental perspectives regarding the current state of care of children with diabetes in Alabama public schools. 170 parents of children with diabetes participated in this study. A school nurse is the only staff member that is allowed by law to administer medication independently. The parents expressed concern about the quality of care when a school nurse is not present (one nurse works in a few schools). Many parents believe that the constant presence of a nurse in school should improve the situation (15).

\section{DISCUSSION}

Current treatment methods for T1DM involve the administration of insulin at doses adjusted to the patient needs, require regular blood glucose monitoring and necessitate adherence to certain rules related to diet and lifestyle (27).

School and preschool activity is a very important part of the life of every child and young adult, including patients with diabetes. Children and adolescents with T1DM should regularly attend school and preschool just like other peers. This approach poses new challenges for the school environment consisting of teachers, supervisors, counsellors, caregivers, school nurses and schoolmates $(3,4)$.

The main responsibility of parents of sick children is to provide supervisors, teachers and a school nurse with information about the child's condition $(2,22)$.

Proper organisation of diabetes care in an educational setting requires training all school employees. It is necessary to accept the rules of self-monitoring and shared responsibility for the quality and organisation of care for a child with T1DM $(3,27)$.

A school nurse should be the person responsible for organising and conducting medical care for children with T1DM (7).

A child with type 1 diabetes requires specialised medical care, including diabetological educational nurses, diabetes educators, dieticians, pediatric diabetologists, children's endocrinologists, psychologists and social workers. The school nurse should work with members of the health care team (36).

The nursing care of children is provided in distinct manners depending on the country $(7,9-12,16,17,21-23,27)$.

According to Hellems and Clarke, $69 \%$ of parents in the USA state that there is a full-time nurse in the school attended by their child with T1DM (10). In contrast, the study by Amilltegui states that only $22 \%$ of schools in Spain employ full-time nurses (7).

In Slovenia, the care of a child with T1DM in school is based on the basic model of school medicine. The most appropriate work location of school nurses is partly in primary health centres and partly in schools $(60.2 \%)$; the most appropriate employer is a primary health centre $(59.4 \%)(36,37)$.

Based on the majority of studies, according to parents and children, the presence of a nurse at school increases the safety of students with T1DM and facilitates improved metabolic control. 
Nguyen et al. performed randomised clinical trial enrolling 36 children with T1DM who were randomised into the intervention group and the control group. They showed that teaching patients, their parents and school nurses the principles of insulin therapy and blood glucose measurements improve the metabolic control of children with T1DM. The disadvantage of this work was a small research group (12).

Type 1 diabetes affects children in different countries. The training of the school team is extremely needed, but expensive. The scope of the responsibilities of a school nurse varies in different countries. In most countries, one school nurse provides service in a few schools, limiting her or his daily availability.

Other works have researched medium- and low-value scientific evidence according to the principles of evidencebased medicine. The majority are non-randomised clinical studies, which differ in terms of the examined population. The studies were conducted in the following groups: ill children, their parents and school staff.

Children were examined in the works of Nguyen et al. (12).

In contrast, parents were examined by Amiltegui et al., Driscoll et al., Hellems \& Clarke, Schmidt et al. and Skelley et al. (3, 7, 10, 15, 32).

Children and their parents were examined by Cox et al., Hayes-Bohn et al. and Lehmkuhl \& Nabors $(8,9,11)$.

In contrast, children, parents and school staff were examined by Peery et al. and Schwartz et al. $(13,14)$.

Studies examining a large population have greater value. In the presented studies, the number of participants ranged from 30 to $499(7,9)$.

The analysed studies utilised different research methods, most frequently questionnaire surveys and interviews Therefore, it is difficult to conclusively compare the results of these studies.

Databases searches provided the following two reviews: Edwards et al. and Kelo et al. The authors of these works encountered similar difficulties. In no cases was it possible to perform a meta-analysis $(16,17)$.

Progress in the health, safety and education of a child with T1DM depends on the cooperation of parents, school staff (teachers), school nurses and health care team (24). Raising awareness of T1DM should be an important element of the education of all caregivers. The presence of a nurse at school helps children follow the rules of self-management and increases their safety at school. According to the surveyed children with diabetes and their parents, every school should hire a full-time, trained nurse who is aware of the children' needs.
Diabetes should not be the reason to exclude a child from any kind of preschool and school activity. Education and social acceptance of a patient with T1DM are essential in school (15).

The ability of children with T1DM to comply with the principles of self-monitoring at school is a key factor in their participation in all school activities (15).

\section{CONCLUSIONS}

According to parents and children with type 1 diabetes mellitus, various forms of support (i.e., checking blood glucose, giving insulin, giving glucagon, treating low and high blood glucose levels, carbohydrate counting) of school nurses are effective and should have an impact on the condition, improvement of metabolic control, school activity and safety at school.

\section{CONFLICTS OF INTEREST}

The authors declare that no conflicts of interest exist.

\section{FUNDING}

None.

\section{ETHICAL APPROVAL}

Review articles were studied.

\section{REFERENCES}

1. Patterson CC, Dahlquist GG, Gyürüs $E$, Green A, Soltész G, the EURODIAB Study Group. Incidence trends for childhood type 1 diabetes in Europe during 1989-2003 and predicted new cases 2005-20: a multicentre prospective registration study. Lancet. 2009;13:2027-33. doi: 10.1016/s0140-6736(09)60568-7.

2. MacLeish SA, Cuttler L, Koontz MB. Adherence to guidelines for diabetes care in school family and school nurse perspectives. Diabetes Care. 2013;36:52. doi: 10.2337/dc12-2083.

3. Driscoll KA, Volkening LK, Haro H, Ocean G, Wang Y, Jackson CC, et al. Are children with type 1 diabetes safe at school? Examining parent perceptions. Pediatr Diabetes. 2015;16:613-20. doi: 10.1111/ pedi. 12204.

4. Wodrich DL, Hasan K, Parent KB. Type 1 diabetes mellitus and school: a review. Pediatr Diabetes. 2011;12:63-70. doi: 10.1111/j.13995448.2010.00654.x.

5. Owens-Gary MD, Allweiss P. Addressing diabetes and depression in the school setting: the role of school nurses. NASN Sch Nurse. 2013;23:15-9. doi: 10.1177/1942602×12467650. 
6. University Library. Evidence Based Medicine: PICO. Accessed April 21th, 2016 at: http://researchguides.uic.edu/c. php?g=252338\&p=1683349.

7. Amillategui B, Calle JR, Alvarez MA, Cardiels MA, Barrio R. Identifying the special needs of children with type 1 diabetes in the school setting. An overview of parents' perceptions. Diabet Med. 2007;24:1073-9. doi: 10.1111/j.1464-5491.2007.02250.x.

8. Cox ED, Fritz KA, Hansen KW, Brown RL, Rajamanickam V, Wiles $\mathrm{KE}$, et al. Development and validation of PRISM: a survey tool to identify diabetes self-management barriers. Diabetes Res Clin Pract. 2014;104:126-35. doi: 10.1016/j.diabres.2014.01.015.

9. Hayes-Bohn R, Neumark-Sztainer D, Mellin A, Patterson J. Adolescent and parent assessments of diabetes mellitus management at school. J Sch Health. 2004;74:166-9. doi: 10.1111/j.1746-1561.2004. tb08215.x.

10. Hellems MA, Clarke WL. Safe at school: a Virginia experience. Diabetes Care. 2007;30:1396-8. doi: 10.2337/dc07-0121.

11. Lehmkuhl $H$, Nabors L. Children with diabetes Satisfaction with school support, illness perceptions and HbA1c levels. J Dev Phys Disabil. 2008;20:101-14. doi: 10.1007/s10882-007-9082-4.

12. Nguyen TM, Mason KJ, Sanders CG, Yazdani P. Targeting blood glucose management in school improves glycemic control in children with poorly controlled type 1 diabetes mellitus. J Pediatr. 2008;153:5758. doi: 10.1016/j.jpeds.2008.04.066.

13. Peery Al, Engelke MK, Swanson MS. Parent and teacher perceptions of the impact of school nurse interventions on children's selfmanagement of diabetes. J Sch Nurs. 2012;28:268-74. doi: 10.1016/j. jpeds.2008.04.066.

14. Schwartz F, Denham S, Heh V, Wapner A, Shubrook J. Experiences of children and adolescents with type 1 diabetes in school: survey of children, parents and school. Diabetes Spectr. 2010;23:47-55. doi: 10.2337/diaspect.23.1.47.

15. Skelley JP, Luthin DR, Skelley JW, Kabagambe EK, Ashraf AP, Atchison J.A. Parental perspectives of diabetes management in Alabama public schools. South Med J. 2013;106:274-9. doi: 10.1097/ smj.0b013e31828de4a4.

16. Edwards D, Noyes J, Lowes L, Spencer LH, Gregory JW. An ongoing struggle: a mixed-method systematic review of interventions, barriers and facilitators to achieving optimal self-care by children and young people with type 1 diabetes in educational settings. BMC Pediatr. 2014;14:1-27. doi: 10.1186/1471-2431-14-228.

17. Kelo M, Martikainen M, Eriksson E. Self-care of school-age children with diabetes: an integrative review. J Adv Nurs. 2011;67:2096-108. doi: 10.1111/j.1365-2648.2011.05682.x.

18. Boden S, Lloyd CE, Gosden C, Macdougall C, Brown N, Matyka K. The concerns of school staff in caring for children with diabetes in primary school. Pediatr Diabetes. 2012;13:e6-e13. doi: 10.1111/j.13995448.2011.00780.x.

19. Chien SC, Larson E, Nakamura N, Lin SJ. Self-care problems of adolescents with type 1 diabetes in Southern Taiwan. J Pediatr Nurs. 2007;22:404-9. doi: 10.1016/j.pedn.2006.05.011.

20. Ginsburg KR, Howe CJ, Jawad AF, Buzby M, Ayala JM, Tuttle A, et al. Parents' perceptions of factors that affect successful diabetes management for their children. Pediatrics. 2005;116:1095-104. doi: 10.1542/peds.2004-1981.

21. Guo J, Whittemore R, Jeon S, Grey M, Zhou Z, He G, et al. Diabetes self-management, depressive symptoms, metabolic control and satisfaction with quality of life over time in Chinese youth with type 1 diabetes. J Clin Nurs. 2014;24:1258-68. doi: 10.1111/jocn.12698.
22. Marshall M, Gidman W, Callery P. Supporting the care of children with diabetes in school: a qualitative study of nurses in the UK. Diabet Med. 2013;30:871-7. doi: 10.1111/dme.12154.

23. Nabors L, Trillett A, Nash T, Masiulis B. School nurse perceptions of barriers and supports for children with diabetes. J Sch Health. 2005;74:119-24. doi: 10.1111/j.1746-1561.2005.tb06655.x.

24. Pinelli L, Zaffani S, Cappa M, Carboniero V, Cerutti F, Cherubini V, et al. The ALBA Project: an evaluation of needs, management, fears of Italian young patients with type 1 diabetes in a school setting and an evaluation of parents' and teachers' perceptions. Pediatr Diabetes. 2011;12:485-93. doi: 10.1111/j.1399-5448.2010.00722.x.

25. Rankin D, Harden J, Waugh N, Noyes K, Barnard KD, Lawton J. Parents' information and support needs when their child is diagnosed with type 1 diabetes: a qualitative study. Health Expect. 2016;19:580-91. doi: $10.1111 /$ hex.12244.

26. Clar Ch, Waugh N, Thomas $\mathrm{S}$. Routine hospital admission versus out-patient or home care in children at diagnosis of type 1 diabetes mellitus. Cochrane Database Syst Rev. 2007;18:1-43. doi: 10.1002/14651858.cd004099.pub2.

27. Marks A, Wilson V, Crisp J. The management of type 1 diabetes in primary school: review of the literature. Issues Compr Pediatr Nurs. 2013;36:98-119. doi: 10.3109/01460862.2013.782079.

28. Parab ChS, Cooper C, Woodlfenden S, Piper SM. Specialist homebased nursing services for children with acute and chronic illness. Cochrane Database Syst Rev. 2013;15:1-36. doi: 10.1002/14651858. cd004383.pub3.

29. Babler E, Strickland CJ. Helping adolescents with type 1 diabetes "Figure it out". J Pediatr Nurs. 2016;31:123-31. doi: 10.1016/j. pedn.2015.10.007.

30. Freeborn D, Loucks CA, Dyches T, Roper SO, Mandleco B. Addressing school challenges for children and adolescents with type 1 diabetes: the nurse practitioner's role. J Nurse Pract. 2013;9:11-6. doi: 10.1016/j.nurpra.2012.11.005.

31. Marshall M, Carter B, Rose K, Brotherton A. Living with type 1 diabetes: perceptions of children and their parents. J Clin Nurs. 2009;18:1703-10. doi: 10.1111/j.1365-2702.2008.02737.x.

32. Schmidt C. Mothers' perceptions of self-care: school-age children with diabetes. MCN Am J Matern Child Nurs. 2003;28:362-70. doi: 10.1097/00005721-200311000-00007.

33. Jackson CC, Albanese-O'Neill A, Butler KL, Chiang JL, Deeb LC, Hathaway $\mathrm{K}$, et al. Diabetes care in the school setting: a position statement of the American Diabetes Association. Diabetes Care. 2015;38:1958-63. doi: 10.2337/dc15-1418.

34. Moher D, Liberati A, Tetzlaff J, Altman DG, The PRISMA Group. Preferred reporting items for systematic reviews and meta-analyses (PRISMA) 2009. Accessed June 21th, 2016 at: http://www.prismastatement.org/PRISMAStatement/FlowDiagram.aspx.

35. Howick J, Chalmers I, Glasziou P, Greenhalgh T, Heneghan C, Liberati A, et al. Oxford Centre for Evidence-based Medicine - Levels of Evidence (March 2009) Centre for Evidence-Based Medicine (CEBM) University of Oxford. Accessed April 21th, 2016 at: http://www. cebm.net/oxford-centre-evidence-based-medicine-levels-evidencemarch-2009/.

36. Juričič $M$, Dobrin PT, Paulin $S$, Zupančič MS, Bratina N. Health care system for children and adolescents in Slovenia. J Pediatr. 2016;177S:173-86. doi: 10.1016/j.jpeds.2016.04.054.

37. Torkar T, Košnik IG, Savič BS. Presečna raziskava stališč ravnateljev o umeščanju šolske medicinske sestre $v$ Slovenski šolski proctor. Zdr Varst. 2014;53:115-23. doi: 10.2478/sjph-2014-0012. 